\title{
Exploring Student Motivation in Quranic Memorization in Selected Islamic Secondary Schools (a Case Study)
}

\author{
*Nik Md Saiful Azizi Nik Abdullah ${ }^{1}$, Fathiyah Solehah Mohd Sabbri ${ }^{2}$, \\ Rabi'atul Athirah Muhammad Isa ${ }^{3}$ \\ ${ }^{1,2}$ International Islamic University Malaysia (IIUM), Jl Gombak, 53100, Malaysia \\ ${ }^{3}$ Universiti Kebangsaan Malaysia (UKM), 43600 Bangi, Selangor, Malaysia \\ *nikazizi@iium.edu.my
}

\begin{abstract}
This article sought to explore the student motivation in memorizing the Quran. A qualitative study through semi-structured interviews with six participants was done to gain data for this study. The findings showed that parents, teachers and the participants themselves influenced student motivation in memorising the Quran. The role of parental guidance and advice was the most influential factor leading to cause among students in learning the Quran. Implications of this study, the students themselves and teachers also were the source of motivation to memorize. At the same time, teachers should always assist and help students in their memorization of the Quran. That way, students will feel more confident to continue their memorization. Therefore, this study can be helpful as a reference in lowering the gap in motivation in Quranic memorization. Hence, the researchers believe that this study will help the other researchers continue and elaborate more on Quranic memorization about the cause.
\end{abstract}

Artikel ini berusaha menggali motivasi mahasiswa dalam menghafal AlQur'an. Sebuah studi kualitatif melalui wawancara semi-terstruktur dengan enam peserta dilakukan untuk mendapatkan data untuk penelitian ini. Temuan menunjukkan bahwa orang tua, guru dan peserta sendiri mempengaruhi motivasi siswa dalam menghafal Al-Qur'an. Peran bimbingan dan nasehat orang tua merupakan faktor yang paling berpengaruh menyebabkan penyebab di kalangan siswa dalam mempelajari Al-Qur'an. Implikasi dari penelitian ini, siswa sendiri dan guru juga menjadi sumber motivasi untuk menghafal. Pada saat yang sama, guru harus selalu membantu dan membantu siswa dalam menghafal Al-Qur'an. Dengan begitu, siswa akan merasa lebih percaya diri untuk melanjutkan hafalannya. Oleh karena itu, penelitian ini dapat bermanfaat sebagai referensi dalam menurunkan kesenjangan motivasi dalam menghafal Al-Qur'an. Oleh karena itu, para peneliti percaya bahwa penelitian ini akan membantu peneliti lain melanjutkan dan menguraikan lebih lanjut tentang menghafal Al-Qur'an tentang penyebabnya.

Keywords: Challenges, Islamic School, Memorization of the Quran, Motivation, Tahfiz Class.

Received: April 11, 2021; Revised: May 21, 2021; Accepted: June 26, 2021 
101 Al-Hayat: Journal of Islamic Education (AJIE)

e-ISSN: $2599-3046$ (online) | Volume 5, Issue 1 | January -June 2021

p-ISSN:2657-1781 (print)

\section{INTRODUCTION}

Memorization of the Quran started Prophet Muhammad's (peace be upon him) time. Surah Al-Alaq indicates this when it relates the first commandment of Allah to the Prophet to be the study of the Quran. The Prophet (peace be upon him) himself was 'ammi' which means 'illiterate. Since Prophet Muhammad (peace be upon him) was unlettered, he memorized the revelation sent to him gradually through Gabriel. He made sure that he understood the disclosure and learned it well before he taught his companions the revelation.

With the spread of Islam to the whole world, the Prophet (peace be upon him) realized that there was a need for many huffaz to teach the Quran to people. Many companions of Prophet Muhammad (peace be upon him) memorized the Quran when the revelation first came to them through the Prophet.

"Busy people would also memorize the Quran" concluded that memorising the Quran is essential for several reasons such as an immense reward waiting for the memorizer, promise that the memorizer of the Quran enjoyed special status above all human beings. They are placed at the highest level in Jannah (Raghib as-Sirjani, 2015).

This is proven by a hadith narrated by Abdullah ibn Amr that the Prophet said,

"It will be displayed to the companion of the Quran after he has entered Paradise, 'Recite, and rise!' For every verse he recites he will rise one level (in Paradise), until he recites the last verse with him (i.e., in his memory)." (Sunan Abu Dawood: No. 1464).

While in other hadithby Prophet Muhammad (pbuh) where he said,

"The best among you is the one who learns the Quran and teaches it" (AlBukhari: No. 5027).

Muslims all over the world strive to memorize the Quran. In recent times there has been an increased interest in memorization due to parental demand for their children to learn the Quran and the increasing number of programs on tahfiz and dakwah on television. Many people are also more aware that memorising the Quran is essential in their lives, which motivates them to look for people or programs to enhance their Quranic recitation and memorization. In Malaysia, there has been a rise in the number of people undertaking memorization of the Quran at various schools, mosques and homes (Ikhwan et al. 2021).

However, the British and Dutch colonisation led to their culture and religion is influenced by the pre-independence Malaysian education system by the secular system. Based on the review of Che Noraini and Langgulung (2005), they argued that the diverse and broadened curriculum introduced in Islamic school were the reasons which made many Muslim parents trusted the Islamic schools more than the schools which only provided a secular curriculum in the syllabus (Zukhrufin et al. 2021). They summarized the justifications for Muslim parents' choice, such as the high cost of living has 'forced' both Muslim parents to work full-time. Thus they have limited time to educate their children. Next, some parents were not able to impart religious instruction to their children. Islamic Knowledge taught at national schools was considered inadequate. Besides, Muslim parents wished to protect their children from many forms of social illnesses by imparting religious knowledge that could serve as a defence. 
Now, the younger generation gets to learn and memorize the Quran, but the older generation has the opportunity to learn it too. Statistics show more than 815 Tahfiz schools are registered under public and private institutions in Malaysia (DPTN, 2018). In 2019, the approximate number of Huffaz was said to come close to 47,474 students with 5,426 tahfiz teachers (DPTN, 2018). In Selangor, by 2019, there were around 382 Tahfiz institutions in all the districts (PITAS, 2019). Table 1 below shows the distribution of Tahfiz institutions in all communities in Selangor as of 2019.

Table 1. Distribution of Tahfiz institutions in Selangor 2019

\begin{tabular}{ll}
\hline \multicolumn{1}{c}{ District } & No of Tahfiz Institutions \\
\hline Sepang & 24 \\
\hline Hulu Langat & 72 \\
\hline Kuala Langat & 31 \\
\hline Hulu Selangor & 25 \\
\hline Kuala Selangor & 44 \\
\hline Klang & 41 \\
\hline Petaling & 80 \\
\hline Sabak Bernam & 17 \\
\hline Gombak & 44 \\
\hline Maahad Integrasi Tahfiz Sains (JAIS) & 4 \\
\hline Total & 382 \\
\hline \multicolumn{2}{c}{ Sources: Persatuan Institut Tahfìz Al-Qur'an Selangor, 2019 }
\end{tabular}

The opening of many Tahfiz institutions, programs and classes has made it a lot easier for people to memorize the Quran since they are not strictly for children. The first Tahfiz institution, Maahad Tahfiz al-Quran wal Qiraat, known as Darul Quran, can be the starting point for many other educational institutions further to develop their modules and techniques of Quranic memorization.

The government has also agreed to implement the Tahfiz Model Ulul Albab (TMUA) in all public secondary schools using the Integrated Tahfiz Curriculum. The curriculum emphasizes the Quranic approach, encyclopedia approach as well as ijtihadik (highlevel thinking) approach that would enable students to memorize the $30 \mathrm{juz}$ of $\mathrm{Al}$ Quran, become professionals with a solid religious foundation based on Al-Quran and al-Sunnah, competent, credible and concerned, while at the same time optimizing their higher-order thinking skills and building relationship with Allah, the people and the universe (Ikhtisas Circular Letter from Ministry of Education Malaysia, 2016).

Different institutions provide different Tahfiz modules for other purposes. By learning Tahfiz, an individual can get even closer to the Creator while understanding and practising the religion in their lives. Interesting Tahfiz modules, easily accessible institutions for learning, and the affordable fee for Tahfiz program and classes encourage the parents and students because they find it comfortable to learn when they can choose their own time and places to discover. However, no matter how good the Tahfiz programs are, they are not complete without addressing the students' motivation to memorize.

Learning the Quran is not necessarily about how they know, but how much they see and have an interest in the subject during learning. Being motivated would boost the level of perseverance to continue repetition to learn and memorize the Quran. When the students fail to see the necessity of education, they tend to lose interest and do not 
feel motivated in the class (Wirth, K. R. \& Perkins, D. 2007). It does not matter what subject they are learning, and motivation plays a crucial role in encouraging them to learn. Mc Carty and Siccon (2001), as cited in Saudullah Ali (2003), stressed that the lesson itself should be motivational, and the information presented by the teachers should be essential and relevant to the students. This is essential as students' motivation is much affected by the curriculum, syllabus and textbook of the subject, and parents' role in encouraging their children. When students perceive something as relevant and vital to them, they will then find the learning meaningful.

Students should be able to relate what they are reading to the real world in their Tahfiz lesson. Students need to feel the urge and the importance of memorizing the Quran so that they will value what they learn and will be able to spread it to others. Suleiman (2003), as cited in Syarifah Firdaus Kasim (2004), stated that both internal and external motivation plays a significant role in the learners' participation and readiness in the process of learning.

In memorizing the Quran, one ought to have these two elements, understanding and motivation so that that memorization can be made into a meaningful lesson. Entwistle (2003), in his analysis on learning and memorization, showed that learning through repetition contributed to the acquisition of knowledge. Students tend to get bored when they have been memorizing for too long. Thus, they need some motivation for them to keep going. Furthermore, according to Benta and Cremene (2004), as cited in Nor Musliza Mustafa \& Mokmin Basri (2014), when students feel motivated, they can understand better, which supports the students' retention on learning. This is extremely important in memorizing the Quran as students can learn the verses faster when they can comprehend the ayah better.

Sternberg (2003), as cited in Muhammad Ikhwanuddin (2013), mentioned how educational institutions only promote rote learning through recitation and repetition whilst ignoring that evaluation and interpretation are also crucial. Citing Westwood (2004), he added;

Rote learning encourage students to commit to memory information which is not understood and have no functional value, where information stored is not easily retrieved and is also easily forgotten.

Hence, when students memorize the Quran without understanding the meaning of the verse, they could lose their memorization quickly. Studies related to motivation in learning had been developed and discussed for many years. Aragon (2002), in his research basis, asserts that students preferred teachers who provide feedback, actively participated in students' learning, and the materials used in supporting education.

On the other hand, studies on motivation in recitation and memorization of the Quran are scarce. A survey of visually impaired students' attitudes in learning Quranic recitation showed low students' motivation (Hajarul Bahti Zakaria, Ab Halim Tamuri, Norshidah Mohd Salleh \& Mohd Huzairi Awang, 2014). The reason seems to be a lack of motivation from both themselves and the teachers in encouraging them to recite the Quran better.

Additionally, based on the review of studies on Quranic memorization related to motivation, only a few studies about the parental role promoted Quranic memorization. A study done by Norkhairolizah (2005) found that parents played a more significant role in developing children's mindsets and academic goals. At the 
same time, they were pivotal in establishing a routine and monitoring their children's children memorization of the Quran. In addition to that, parents also provided an excellent environment to support their children's Quranic memorization.

While a study on the use of video in increasing students' understanding and motivation shows that it helps in positively encouraging students to be more active and focused, students also understand the lesson better as they became interested in learning (Cik Wan Noorli, Che Haslina \& Tengku Muhaini, 2011).

Based on the studies above, some factors in learning could be highlighted: 1) attitude and interest of the students in learning, 2) motivation from parents and teachers, and 3) the use of instructional material in the class.

Thus, by enhancing students' motivation, it will help minimise the study gap in the field of Quranic memorization. Since the tahfiz program in SMIAAG and SMIAAB are based on the parents' wish for their children to memorize the Quran, it is essential to seek some factors behind students' motivation in learning the Quran. In contrast, at the same time, stress on the barriers faced by students and how they overcome the obstacles while memorizing.

Thus, the current research aims to address these deficiencies in understanding the role of motivation in the memorization of the Quran to provide pragmatic solutions to challenges in maintaining an optimal level of inspiration and memorization as a whole.

As students need motivation in learning, studying the factors behind their eagerness to learn is necessary. This study is set to explore the factors behind motivation in the memorization of the Quran.

\section{Studies on Motivation for Learning}

\section{Motivation for Learning by Oneself}

As every human is created with a good fitrah, it is up to them to behave and act. In the hadith by Sahih Muslim, the Prophet said, 'Every newborn child is born in a state of fitrah. Then his parents make him a Jew, a Christian or a Zoroastrian'. From this hadith, it is clear that humans created as good people. The fitrah instilled in them has been endowed with intellect and free will that helps them differentiate between right and wrong. Through learning, they can boost the level of understanding of some issues, such as the need for motivation in the learning process. They know that without cause to learn, it is impossible to learn by themselves. As Al-Kanderi (2012) mentioned;

Change and personal growth come from within; behavior does not improve spontaneously. Muslims are required to persist in modifying unacceptable behaviors, and to follow up bad deeds with good deeds in order to atone for transgressions. Allah says, "Verily never will Allah change the condition of a people until they change it themselves (with their own souls)" (13:11).

Research done on the factors contributing to students' interest in learning Islamic education found that one of the significant factors affecting the students' interest was an individual's interest in learning (Zaiton Mustafa and Hishamuddin Salim, 2012). This is following the study by Tuckman \& Monetti (2010), where they stated that factors affecting memorization included how much the information gave meaning, its practice and the organization of the data, and how much the data was transferred to an individual. 
Critical reading on devotional reflection on the understanding of the Quran among urban women in Pakistan seems to focus on developing skills for reading and understanding the Quran rather than recitation and memorizing of the verses (Nadia Loan, 2012). As the Pakistani government tried to imply the Quranic law in the country, the urban society somehow was forced to try to understand more about the law through reading. Thus, Nadia concluded that urban women learn to read the Quran to understand the issue better. Instilling motivation to learn the Quran somehow helps encourage urban women to understand the Quranic law implied in their country.

Another study on identifying the level of mastering Hukum Ra in reciting the Quran showed that students' interest and attitudes in the Quran's recitation contributed to the mastery of Quranic recitation (Khairul Adzha Shahrudin, Zaidi Mohamad Nusran \& Siti Jumaah Rahmat, 2015). The result showed that the Quranic recitation lesson was more effective when students have a high level of motivation in learning.

\section{Motivation Towards Learning Through Influence from Parents}

Al-Ghazali (n.d.), in his view on child development, believed that children should be taught about a good character from the earliest days of their childhood. According to him, individuals are influenced from the moment they were born. However, this is not what Al-Ghazali put his focus on. He emphasized the food sources acquired by the parents or guardians being either through lawful or unlawful means. If the parents feed the child with good food, the children are more likely to behave well rather than simply using illegal means to provide the child.

Later on, when the child starts to show some intellect, parents should not ignore them but pay extra attention to the child. This is important as the child had just started to view things as good and evil. He then pointed out that these steps would result in the moral upbringing being practical and fixed in the child's heart even though they have reached puberty. But if the upbringing is not good, the child will grow accustomed to the truth even though they know it is wrong.

Parents are also responsible for providing and giving a suitable environment for Quranic memorization and supporting their children and giving good foods, encouraging cleanliness, discipline and tranquillity, help in enabling the children to memorize the Quran comfortably and confidently. This follows Al-Ghazali's idea that since the first teacher of a child is their parents, it is the parents' responsibility to teach their children proper manners and character (Adam, 2016).

Zaiton Mustafa and Hishamuddin Salim (2012) found that encouragement from parents helps in influencing students motivation in learning. When students get more support and encouragement, they tend to learn more without a reminder to do so.

A study carried out by Norkhairolizah (2005) found that parents played a significant role in developing children's mindset and academic goals while at the same time establishing a routine and monitoring their memorization of the Quran. Through making a timetable for memorizing, parents can discipline their children and help them manage their time spend on something. When they had any problem memorizing any verse, they will seek help from their parents, and parents also can monitor their memorization more effectively.

Pulido et al. (2010), in their study on the intrinsic motivation factors in second language communication skills, highlighted that when parents motivate students to 
learn, they showed that mastery and accomplishment in linguistic skills helped them achieve their goal for the future. Allah ta'ala mentioned in the Quran, which mean;

'You have indeed in the Apostle of Allah a beautiful pattern of conduct for everyone whose hope is in Allah and the Final Day and who engages much in the praise of Allah'. (Surah al-Ahzab: 21).

From this verse, it is evident that the Prophet was sent to be a role model. Hence, people who follow him will also have beautiful conduct. In one of the Prophet's stories, the Quraisy leaders were fighting over who should be the one to put back the hajarul aswad in its place. The Prophet was asked to decide the matter as they trusted the Prophet as a just person. This is one of the proofs showing how the Prophet became a role model for justice and equality until even the Quraisy leaders looked up to him when they could not decide among themselves.

Another example is when a woman gave the Prophet a sour lemon to test him. The Prophet just smiled and finished the lemon without any harsh word. This also can be a guideline on how the teacher should behave in front of the students. The teacher must act appropriately and treat the students with respect, love and understanding. When the teacher shows respect to the students and encourages passion in memorising the Quran, the students will follow it as they trust see the role model behaviour in the teacher.

Many Muslim scholars support this opinion. According to Ibn Khaldun (n.d.), he believed that the relationship between teachers and students should be based on love and understanding. They should act as parents and avoid harsh punishment in teaching the students. In addition, he argued that if the teacher hurt the students emotionally, it could lead to the destruction of a child's personality and development. Maintaining good action and behaviour can increase the tendency for the students to follow the appropriate deed.

The importance of becoming a role model also can be seen from the story of Muhammad al-Fateh during his ruling. He showed the ministers that he was a good leader and was always humble through his action when building the citadel, where he volunteered to work with others. This shows that even though teachers are above the students, there should not be any gap in the relationship so that the students feel close and cared about. It will enable a more effective teaching and learning process since the students do not feel scared to approach the teacher and ask them questions when necessary.

Teachers must also engage in a fruitful teacher-student relationship of mutual respect where the teachers are imparting knowledge and nurturing students. Dr Zakir Hussain, a Muslim intellectual and the founder of Aligarh University in India, debated that the educational system in his country was based on what the authority thought ideal for the society. Hence, students were not allowed to develop their thinking. To make it worse, there was a lack of good teachers who treated their students with love and kindness and not with cruelty, harshness and authority.

According to the Social Learning Theory by Albert Bandura, he argued that children tend to observe people's behaviour. Thus, everything that they had followed can be considered models. Many models can influence them in imitating the behaviour, including teachers at school. Bandura believed that children might imitate the 
behaviour they observed without thinking about whether the behaviour is appropriate or not.

Being role models can be seen through their language and action, whether inside the classroom or outside. This method does not emphasize delivering knowledge and information like the lecture method, but rather showing good character unconsciously while motivating others to follow. Teachers provide a frame of reference for students to act and behave.

For example, when the teacher is speaking softly to the students, the students will be influenced to respond softly to the teacher. This is the first step in encouraging them to be polite and speak nicely to their parents and friends. On the other hand, if the teacher speaks loudly and uses harsh words, they might follow them. Hence, the teacher must control themselves and talk appropriately.

According to Qarashi, there are some guidelines and things that the teachers should always be aware of and keep in mind. First, teachers should possess noble qualities which helps develop students' good character for their future. One of the qualities includes the ability to be disciplined in carrying out the command of Allah. Hence, teachers must show themselves worthy as a servant of Allah for the younger generation of Muslims.

To do that, they must live up to the teachings of Islam. The problem with teachers nowadays is that they do not practice what they teach. As a result, students find it challenging to understand and follow the right way of Islam. He suggested that teachers perform ritual prayer in the school to see them and avoid idle chatting during their free time. Rather than talking unnecessarily, teachers could perform Sunat prayer or read an Islamic book to make prudent use of their time.

An ideal teacher is the one who shows good traits in their personality. The features can be seen from their appearance, enthusiasm, initiative, open-mindedness and pleasant manners. No doubt that every human being loves to see pretty things. Like the beautiful flowers with a good fragrance that attracts others to see, teachers can also attract students to learn virtue and character through the proper conduct in their thought, word, and deed. When the teacher deals with inappropriate ways while listening to students' memorization, students will learn the appropriate course of dealing with their friends, parents, and others, especially while communicating.

Some Muslim scholars suggest that teachers take care of their external appearance regarding how they dress since it has a psychological effect on students. They believe that teachers can win the attention and love of the students by maintaining an attractive appearance. In addition to that, teachers can stimulate learning more effectively when they are tolerant, kind, fair and straightforward. So, the ideal teacher is the one who gives an impression on how to have a good life that the students can follow.

Teachers also must take care of themselves well in terms of cleanliness of their body, clipping their nails and addressing body odours. In addition, they can vary their clothing so that students will not feel bored to see them, and students will feel comfortable learning and memorizing the Quran in front of the teachers.

As mentioned earlier, role modelling also takes place outside the classroom. Thus, students can experience their teachers in actual life situations. Schleifer (1988) said that it is effective as they learn and explore how they will use the value they have learnt in their practical life. Thus, they can experience it firsthand. 
Hassan Langgulung supports this in his essay 'Teacher's Role and Some Aspects of Teaching Methodology: Islamic Approach'. He suggested that the moral values of the teachers are unlimited outside the teacher-pupil interaction in the classroom.

A good role model is someone who can be a mentor to others. As a mentor is defined as someone who takes a particular interest in helping others develop and optimise their potential, teachers are the perfect example to be mentors to the students. This concept has been found applicable in the process of teaching and learning. Mentoring differs from advising in terms of the quality of the relationship.

Mentoring develops over a long period, according to the students' needs. Hence, teachers are more aware of the changes needed in students, so the attention, advice, information and encouragement needed vary based on what the teachers see from the students. Since effective mentoring is based on mutual trust, understanding and empathy, it helps advance the educational and personal growth of the students as teachers will listen to their problems in learning. The role model method allows mentoring students, and it is easy for teachers to access them by observing them in the class. Since an older person usually does mentor a younger person, experiences from the older person can inspire the younger ones. The intimate relationship between the more senior and the younger people leads to meaningful interactions and shared experiences that lead to mutual respect. Other than that, teachers should follow virtuous and pious people such as the Prophet and the companions' way of life as guidance. When the teacher acts with honesty and discipline, it helps motivating students to work harder and be disciplined in their timing for study and others matters.

In addition to that, teachers can show the students that they care about their well-being by asking them their feelings and thoughts about the class. Moreover, when students are frequently absent from the course, it is the responsibility of the teachers to find out the reason and figure the best solution to solve their problem.

Commandingproper behaviour and preventing the bad one is essential in Islam. Many verses in the Quran stress the importance of teaching and practising good deeds by every Muslim. According to Ahmad (1987), the importance of commanding the right and forbidding the wrong is a mechanism for Muslims to fight against social, moral and spiritual diseases and have a healthy and dynamic life.

From Abi Said al-Khudri r.a. "If one of you sees something wrong, let him change it with his hand; if he cannot, then with his tongue; if he cannot, then with his heart and this is the weakest faith."

According to Ahmad (1987), the elaboration of this hadith shows that there are some methods or guidelines on how to deal with proper and improper behaviour. Teachers can make use of it in their effort to nurture upright students. First, by hand in which the teachers show the appropriate way to deal with a situation. Then, it can include legal action based on the rules and regulations of the school.

Other than that, teachers can advise the students using words. Ahmad (1987) said that sometimes teachers could use soft words, and harsh words should be avoided. There should also be time when teachers scold the students in private to not feel humiliated to be reprimanded in front of their friends. However, there are also times when the teachers need to scold the students in public to remind others not to make the same mistake. 
The role model teacher may use this method since students will note the proper way to deal with any situation if it happens later on. As mentioned in the Quran where Prophet Nuh a.s said which mean;

"So I have called to them aloud. Further, I have spoken to them openly in public as well as secretly in private" (71:8-9).

Teachers can use this in commanding the right and forbidding the wrongdoing of the students. For example, when a student hit another student in the class, teachers can use this method to correct the students. At first, the teacher may advise the student privately about the matter. However, if it does not leave an impression on the student, they may try to speak and scold the student in front of the classmates. Sometimes, students tend to behave differently in front of the teacher and another way when around friends.

When students make mistakes, teachers should kindly bring to light the mistake they made. This is to ensure that students really understand the error and do not commit the same things again. Moreover, teachers should realize the students' capacity when delivering a lesson and not ignore their questions when asked. Teachers' approach can encourage students to be brave and have the courage to learn in the class, especially the low achiever.

Other than that, teachers should maintain the same rules and discipline and carry out good actions as it can urge students to work hard. They also can help encourage the students to repeat the lesson to make the students memorize. If the teachers use this method frequently, it can turn into a habit for students to learn the lesson easily.

Good teachers will not neglect the feeling of the students and will listen to them well. They are aware of the environment of the class and recommend the bored students to relax for some time to show that they care about the well-being of the students. Thus, the students will feel like they are being cared for and will continue the lesson happily without any complaints.

Since the teachers who are the role models understand students the best, they will avoid doing something that can annoy the students or result in protests. Sometimes, the lesson time can be reduced, and the lesson simplified so that there will be time for teachers to interact one to one with the students.

As students trust their teacher, they do not worry about being embarrassed because they know any misbehaviour or mistake will be addressed privately. Students will then turn to their teacher because they feel that they will be listened to when they struggle with any problem, such as interpersonal relationship issues or academic issues. Furthermore, they know that any problem discussed will be kept only between them unless more incredible difficulty arises.

Fairness is closely related to trust, as students know that their teachers will not discriminate or treat them differently. Although proper means treating every student equally and letting them have the same opportunity, sometimes there is a need for teachers to do the other way around. For example, a teacher may reward a student based on how much they improve in their learning. In this case, teachers give every student an equal chance to get a good grade, but some need extrinsic motivation to improve in their learning. 
A study on the factors influencing students' interest in learning showed that teachers are an influential role model in shaping the interest and attitude of the students in learning at school (Zaiton Mustafa and Hishamuddin Salim).

While another study on 206 American Indian students on motivation towards learning styles shows that they preferred a teacher-structured environment through feedback, active participation and the use of media to facilitate learning. (Aragon, 2002).

While Ghenghesh (May 2010) found that motivation of a heterogeneous group of students studying Arabic as a second language was affected by the role of the teacher in determining attitude towards the language and in supplying motivation, in addition, learning context also influences students' motivation.

Saudullah Ali (2003)stressed that teachers were an essential source of motivation for the students. He reported that students preferred teachers who were always available when they could support and advise the students in their learning.

Furthermore, Adam (2016), as cited in Palmer (2007); Debnath (2005); D'Souza \& Maheshwari (2010), stated that students' motivation could be deepened when they were exposed to a wide range of motivational experiences. He added that teachers should also give room for students to choose their methods of learning while at the same time providing unending support and trusting them.

3. Motivation Towards Learning Through the Use of Instructional Materials in the Class

A study on the use of video in increasing students' understanding and motivation showed that it helped in positively encouraging students to be more active and focused. In addition, students also understood the lesson better as they became interested in learning (Cik Wan Noorli, Che Haslina \& Tengku Muhaini, 2011).

The curriculum provided in the subject was one of the major factors affecting students' interest in learning (Zaiton Mustafa and Hishamuddin Salim). In addition, research on student motivation towards learning style substantiated that when students structured their environment, it could encourage them to compete with one another in learning (Aragon, S.R., 2002).

\section{Motivation Towards Learning through Influence from Peers}

According to Latefah Al-Kanderi in her review on Prophet as educator mentioned that,

The Prophet Muhammad said, "The person follows the religion [or habits] of his friends; so each one should consider whom he makes his friend."

Tongsilp (2013), in his path analysis of the relationship between factors and achievement motivation of 840 students of private universities in Bangkok, found that academic achievement, future expectation and self-directed learning were correlated with achievement motivation. However, the classmate relationship did not have a direct effect on achievement motivation.

A study on learning motivation of 291 students of Islamic studies in University Kebangsaan Malaysia identified some factors that could enhance learning including choice of peers (Salasiah, et al, 2011). 


\section{Theoretical Framework}

Scholars had long discussed studies related to motivation. However, studies based on Islam have just recently increased in number. Since this study focused on the reason in Quranic memorization, which falls under Islamic studies, it is essential to point out the Islamic perspective. Seifert (1999) mentioned;

Motivation refers to the impact of reinforcement on behaviour. Support that works effectively is considered to be motivating. For example, if receiving gold stars for academic performance makes a student work harder, then gold stars boost; if praise is what works, then credit is inspiring (p.181).

Motivation in Islam can be divided into two, namely intrinsic and extrinsic motivation. Intrinsic motivation comes from one's own desire to achieve or overcome challenges. So, they do not need any incentive to encourage them to do any work. The satisfaction coming from the work itself is a reward for them. Extrinsic motivation refers to motivation to perform a behaviour to get tips and avoid punishment (Alizi and Mohammad Zaki, 2005). They added that intrinsic motivation might decrease due to extrinsic rewards.

Alizi and Mohammad Zaki (2005) then supported their argument by raising questions on whether Muslims should perform ibadah as a submission to Allah or because they are afraid of the consequences of not acting or neglecting it. They then pointed out that those with a high level of iman would be more likely to perform ibadah for the sake of Allah.

Extrinsic motivation can help teachers in motivating students. Gold stars, tokens, candy, stickers, honour rolls, special treats like field trips, praise, test grade and class rank are among the familiar extrinsic motivators teachers routinely use by providing students with something they desire. (Fuhrman \& O'day., 1996, p.34).

While Ola Abdel-Kawi and James Kole (1991) stated that extrinsic motivation helped encourage Muslims to do better. In their observation of the process of inspiration, an Islamic model of the process was developed. The model involved a sequence; it started with explaining the rewards given, the witnessing of past experiences that were satisfactory and then followed by the good conduct of behaviour.

Chang (2005), as cited in Garcia \& Pintrich (1996), then defined intrinsic motivation as participation in an activity due to curiosity and one's desire to engage and contribute to something. When students engage in this kind of motivation, they tend to develop a goal that they want to achieve regardless of the difficulties they may face. In addition to that, Chang (2005), as cited in Dev (1997), also defined extrinsic motivation. These are outside motives that developed from the goal provided in front of them. He gave the example of a student who studied hard to get a good grade to get a new car. Thus, learning through extrinsic motivation can hardly lead students to look for knowledge, but other things manipulated it.

Salasiah et al. (2011), in their research on students' motivation in Islamic education, provide an overview of the factors behind their motivation. The figure below shows their model of learning motivation factors. 


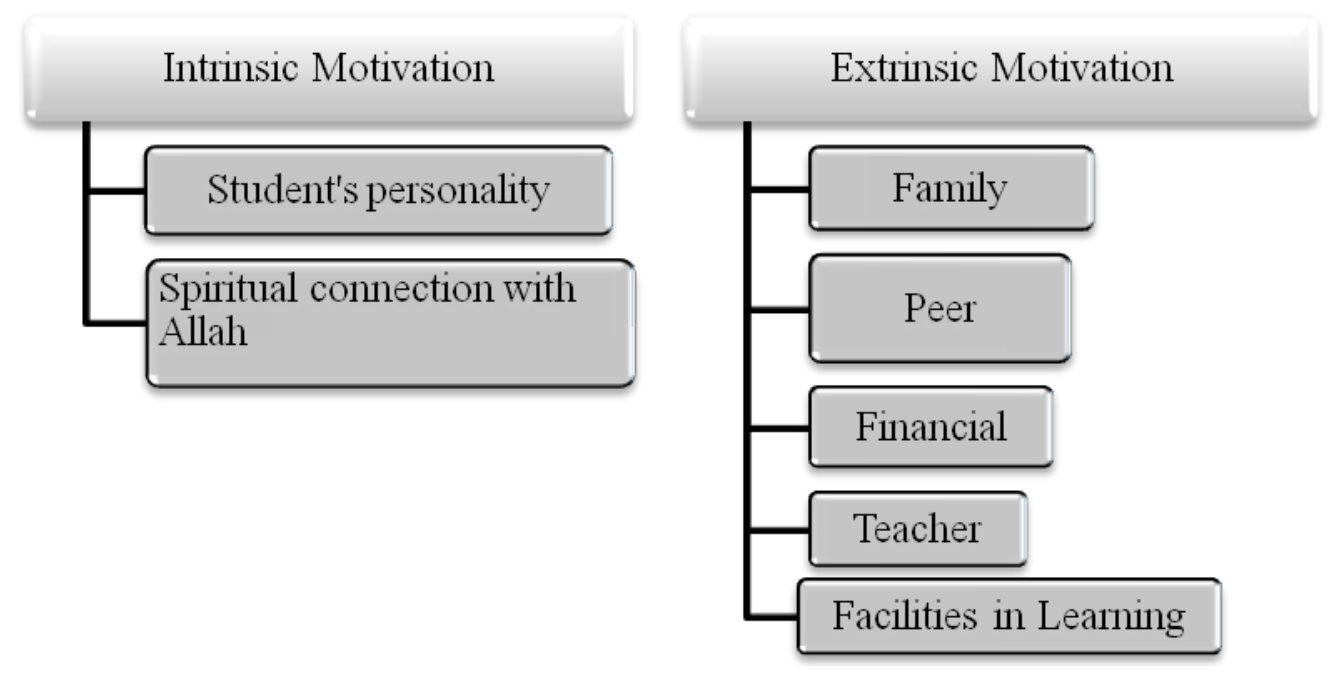

Figure 1. Learning Motivation Factors adapted from Salasiah, et al (2011)

\section{Motivation}

Oxford Dictionaries online (2014) defined motivation as a reason or reason for acting or behaving in a particular way. While according to Huitt, W. (2011), as cited in Franken (2006), added arousal, direction and persistence of behaviour as components in understanding motivation. Salasiah et al. (2011), as mentioned in Najati (1985), defined motivation as spiritual self-encouragement.

Meanwhile, in defining motivation, The American Educators' Encyclopedia (n.d.) stated that it is a psychological concept in human behaviour that describes a predisposition towards a particular behaviour to satisfy an individual need.

Motivation is defined as a theoretical construct used to explain the initiation, direction, intensity, and persistence of behaviour, especially goal-directed behaviour. Motivation refers to students' subjective experiences, especially their willingness to engage in lessons and learning activities and their reasons. (Brophy, J., 1998, p.51).

In addition, in their definition of motivation, Surina Nayan, Krishnasamy, H. N. \& Latisha Asmaak Shafie (2014) said that motivation could be seen in four aspects; goal, behaviour to reach the goal, desire to achieve the plan and positive attitudes towards the goal.

Huitt (2011) believed that the surrounding is the primary factor of learning and motivation. While Ames (1992) and Dweck (1986) as cited by Huitt (2011) proposed that environment, attitude and perception of oneself are interrelated in the sense that it completes one another.

\section{Students' motivation}

Brophy, J. (1988), as cited by Azizi Yahaya (2006) in his definition of students' motivation to learn, said that it is a situation where the student himself finds learning as being meaningful, and he tries to benefit from the knowledge by himself. He added by pointing out several elements of motivation to learn: planning, concentration on the goal, awareness of the plan, active search for new information, and many more. 
113 Al-Hayat: Journal of Islamic Education (AJIE)

e-ISSN: 2599-3046 (online) | Volume 5, Issue 1 | January - June 2021

p-ISSN:2657-1781 (print)

\section{METHOD}

This study is a qualitative case study using in-depth, semi-structured interviews through one on one interactions. The researchers used an open-ended interview structure that included specific questions, followed by probing questions to investigate the phenomenon in detail. The participants were asked a standardised set of questions.

Participants in this study were 6 Tahfiz students ( 3 females and 3 male) out of 395 Tahfiz students in the school who their teachers selected through purposive sampling. Their ages ranged from 15 to 17 years old who were currently taking Tahfiz Al-Quran program in Sekolah Menengah Islam Al-Amin Gombak and Al-Amin Bangi. Three participants were selected from SMIAAG (1 male and 2 females), while the other three were chosen from SMIAAB ( 2 male and 1 female). Each participant had been exposed to Quranic memorization for at least two years.

From the students' name list, every number two student was being picked as a sample. Since there were not too many Form 4 students on the list, it was easier to select the participants of this study.

Table 2. Characteristics of the Participants

\begin{tabular}{lll}
\hline Characteristics & Gender & N \\
\hline SMIAAG & Male & 1 \\
& Female & 2 \\
\hline SMIAAB & Male & 2 \\
& Female & 1 \\
\hline$N=$ indicate the number of students involved
\end{tabular}

$N=$ indicate the number of students involved

The interview was transcribed using verbatim transcription, coded and analysed using thematic analysis. The coding included the factors leading to students' motivation in memorizing the Quran (e.g., family, teachers, etc.).

\section{RESULT AND DISCUSSION}

\section{Factors Influencing Students' Motivation in Memorization of the Quran}

Table 3. Three major factors of students' motivation in Quranic memorization

\begin{tabular}{|c|c|c|c|}
\hline Participant & $\mathbf{F}$ & $\mathbf{S}$ & $\mathbf{T}$ \\
\hline P1 & $\checkmark$ & $\checkmark$ & \\
\hline P2 & $\checkmark$ & & \\
\hline P3 & $\checkmark$ & & $\checkmark$ \\
\hline $\mathrm{P} 4$ & $\checkmark$ & $\checkmark$ & \\
\hline P5 & $\checkmark$ & & \\
\hline P6 & $\checkmark$ & $\checkmark$ & \\
\hline
\end{tabular}

$F=$ indicated family influence, $S=$ indicated self-influence, $T=$ indicated teachers' influence

Table 3 above presents three major factors shaping students' motivation in the memorization of the Quran. All participants agreed that their family's influence was the main reason for their motivation in memorization. Only three participants agreed that they themselves were motivated to memorize the Quran followed by only one participant thought that teachers were the ones who motivated them to memorize. 


\section{Family Influence}

It is undeniable that the bond between family members is more vital than any other kind of bond. Like the Malay proverb, 'Air dicencang tidak akan putus', which means that even though there are differences among them, they are still connected and share things in common. This is what a family should be like. Thus, the family can have a significant impact on the life decisions and experiences of an individual.

Table 4 Summary of family factors from both school

\begin{tabular}{ll}
\hline \multicolumn{1}{c}{ SMIAAG } & \multicolumn{1}{c}{ SMIAAB } \\
\hline $\begin{array}{l}\text { P1: check on their memorization, } \\
\text { monitor their memorization, manage } \\
\text { their time }\end{array}$ & $\begin{array}{l}\text { P4: influence from their parents to } \\
\text { memorize }\end{array}$ \\
\hline P2: inspiration from their siblings (sister) & $\begin{array}{l}\text { P5: motivated to be a role model for } \\
\text { others }\end{array}$ \\
\hline $\begin{array}{l}\text { P3: be motivated from other siblings' } \\
\text { Quranic memorization }\end{array}$ & $\begin{array}{l}\text { P6: influence from their parents to } \\
\text { memorize }\end{array}$ \\
\hline$P=$ indicate participant &
\end{tabular}

As per table 4 above, the researcher found that most participants are motivated to memorize the Quran due to their family's influence, from both their parents and siblings. However, only two of them argued that only their siblings motivate them to memorize the Quran 'P3: be inspired from other siblings' memorization' and 'P5: motivated to be a role model for others.

"Every morning, before going to school, my father will check our memorization first..." (Participant 1).

"my family, especially my older sister..she really inspires me to memorize" (Participant 2).

"but not only my mother, my father and other siblings also gave a lot of advice" (Participant 3).

Throughout the interview, the researcher found that the strict teaching, management of time, and encouragement from someone close were the leading modes of influence. Participant 1 said;

"... if we failed to memorize clearly, he will add another 3-4 ayah and for us to memorize when we are back at home..."

This indicates the strictness in teaching memorizing as the participant needed to learn the Quran correctly to avoid punishments, although it was a suitable punishment. The participant added by saying that her mother was the one who managed her time to memorize while at the same time monitoring her memorization;

"well, aside from my father, my mother also monitor our memorization sometime".

"...she is more focus on how we manage our time in memorizing and other things...".

Apart from that, the other participants identified inspiration from someone close. Participant 2 says; 
"...especially my older sister, she really inspires me to memorize"

While participant 3 mentioned that all of her siblings had memorized the Quran, she also became motivated to learn it. In addition, her mother also gave quite profound and poignant advice, which encouraged her more.

"Praise be to Allah, all my family members have memorized the Quran, only $m$ youngest sibling and I haven't finished memorizing. the youngest. I think has around 10 chapters more to go".

"advice from my mother, she really wants all her children to memorize the Quran as that's the only valuable possession she can give us, and she reminded us that memorizing is easy, but to maintain our memorization until the end of our lives is what is hard, even if we want to further our studies or go somewhere, the things she would like us to always keep in mind is to take care of our Quranic memorization"

Meanwhile, both participants 4 and 6 agreed that their parents were the ones who admitted them to the program. In contrast, participant 5 said that he asked his parents if he could enrol into the Tahfiz program as he wanted to encourage his siblings to follow him in memorizing the Quran.

"maybe I could say my parents and relatives, according to what my mom had said before, my KAFA teacher always told her to send me to any memorization class if possible as my recitation was very good" (Participant 4).

"both my father and mother admitted me here" (Participant 6).

"I want my siblings to follow my path" (Participant 5).

Results from the interview showed that participants from both schools had the same thought that their family members are the most influential persons in their motivation to memorize. To conclude, it is essential to realize that family plays a vital role in influencing and increasing students' motivation in memorizing the Quran. This is because other than at school, and students spend most of their time at home. What they see can change their thoughts about the world. Children tend to imitate something they see as good and exciting. That is why it is essential to develop children's minds on memorizing the Quran.

\section{Self-Influence}

Table 5. Summary of self-factor from both school

\begin{tabular}{ll}
\hline \multicolumn{1}{c}{ SMIAAG } & \multicolumn{1}{c}{ SMIAAB } \\
\hline $\begin{array}{l}\text { P1: want to live and die with Quran, } \\
\text { able to perform prayer better }\end{array}$ & $\begin{array}{l}\text { P4: able to control their } \\
\text { emotion }\end{array}$ \\
\hline P2: - & $\begin{array}{l}\text { P5: would like to be an } \\
\text { example to their siblings }\end{array}$ \\
\hline P3: - & $\begin{array}{l}\text { P6: through memorization, they } \\
\text { can have strong memory }\end{array}$ \\
\hline
\end{tabular}

$P=$ indicate participant

Another undeniably influential factor in memorising the Quran, as reported by the participants, is self-interest. Some of the reasons that could be identified were knowing the importance of learning, improving performance in prayer and controlling emotion, 
setting an example, and having a solid memory. Table 5 above also shows that when asked about their motivation to memorize, some students had nothing to say about it (P2 and $\mathrm{P} 3$ ).

"I myself think that it is important to live and die with Al-Quran. So I can say that this is what motivated me to further memorizing of the Quran" (Participant $1)$.

"I guess I can say that I memorize the Quran to be able to perform prayer even better with choices of verses to pick".

"well I think when I memorize the Quran, I am able to control my emotion" (Participant 4).

"I think me myself are motivated to learn the Quran more..since I am the oldest in my siblings, I would like to be an example to my siblings" (Participant 5).

"emm, I think it is because I heard that people who memorize a lot have stronger memory, learn easily, maybe that's why I am more interested in memorizing, before, I couldn't understand what I read, but now I can understand a bit" (Participant 6).

From the interview, the researcher concluded that only one participant from SMIAAG believed that it is essential to memorize the Quran 'P1: want to live and die with Quran, able to perform prayer better' while all three participants from SMIAAB thought that it was good to memorize the Quran. However, they had not chosen to start learning on their own. This is based on the statement, 'P4: able to control their emotion', 'P5: would like to be an example to their siblings', and 'P6: they can have strong memory through memorizing the Quran'.

\section{Teacher Influence}

Interestingly, only one participant mentioned that teachers gave a lot of support in memorizing;

"at school, the teachers also taught a lot and helped me in memorizing" (Participant 3).

The interview highlighted that there is a lack of motivation and encouragement from teachers. This indicates that teachers may not utilise and take up their roles in supporting memorization for various reasons. When the researcher asked about the teachers in the class, most of them had just shaken their heads and said that the teachers begin their courses with the recitation of the Quran with the minimal translation of the verses. To summarize, it is clear that some are lacking in the teachers' role in motivating their students to memorize the Quran better.

\section{Factors Underlying Student Motivation in Memorizing the Quran}

Based on the study, the researcher found that three primary factors influencing students' motivation are family, the students themselves and teachers' role in promoting the cause. This is in line with Al-Ghazali (n.d.), in his view on child development, who believed that children should be taught good character from the earliest childhood. According to him, individuals are influenced from the moment they are born and moved. However, this is not what Al-Ghazali put his focus more on. He emphasized the food sources acquired by the parents or guardians either through lawful or unlawful means. If the parents feed the child good food, the children are 
more likely to behave well rather than use the illegal means to get food to feed the child.

Later on, when the child started to show some intellect, parents should not ignore it but pay extra attention to the child. This is important as the child had just started to view things as good and evil. He then pointed out that the moral upbringing will be practical and fixed in the children's hearts though they reach puberty. But if the upbringing is not good, the child will grow accustomed to mess around and avoid accepting the truth though they know it is wrong.

According to Zaiton Mustafa and Hishamuddin Salim (2012), they found that the encouragement from parents help in influencing students motivation in learning. A study earned out by Norkhairolizah (2005) found that parents played great role in developing children's mind setting and academic goal, while at the same time establishing routine and monitoring their memorization of the Quran.

In addition to that, parents also provided and gave a suitable environment for Quranic memorization and provided support to their children. This is according to Al-Ghazali's idea that since the first teacher of a child is the parents, it is the parents' responsibility to teach their children proper manners and character (Adam, 2016).

Pulido et al. (2010), in their study on the intrinsic motivation factors in second language communication skills that motivate students to learn, showed that mastery and accomplishment in linguistic skills helped them achieve their goal for the future.

This finding also supports the other result of Brophy (2008), where students interested in learning can be maintained through the teacher's role in assisting their interest. Islam also identifies it as part of worship that is inherent in humans.

A role model can be seen through language and action, whether inside the classroom or outside the school. This method does not emphasize delivering knowledge and information like the lecture method but instead showing the good character unconsciously to make others easy to follow. Teachers provide a frame of reference for students to act and behave.

For example, when the teacher is speaking softly to the students, the students will be influenced to respond softly to the teacher. This is the first step to encourage them to be polite and speak nicely to their parents and friends. If the teacher talks loudly and uses harsh words, the students might follow them. Hence, the teacher must control and speak using the right style.

As mention earlier, role models also take place outside the classroom. Thus, students can experience themselves in actual life situations. Schleifer (1988) said that it is adequate to learn and explore how they will use the value in practicality. They can experience it in front of them as they see it firsthand.

Hassan Langgulung supports it in his essay 'Teacher's Role and Some Aspects of Teaching Methodology: Islamic Approach'. He suggested that the moral values of the teachers are unlimited outside the teacher-pupil interaction in the classroom. According to Quarashi, he provided some guidelines and things that the teachers should always be aware of and remind. Teachers should possess noble qualities which helps developing students' good character for their future. One of the qualities includes the ability to present discipline in doing the command of Allah. Hence, 
teachers must show themselves worthy as a servant of Allah for the younger generation of Muslim.

To do that, they must utilize the teaching of Islam to the students. The problem in teachers nowadays is that they do not practice what they teach. This makes students difficult to understand and follow the right way of Islam. He suggested teachers perform ritual prayer in the school where students can see and avoid nonsense chitchatting during their free time. Rather than talking unnecessarily, the teacher can perform Sunat prayer or reading Islamic book to fill in their time. Students tend to be motivated to learn and memorize the Quran when they see their teacher spending time wisely.

There is no doubt that technology is the whetstone that can sharpen the learning process. It also opens and expands the minds of people towards the new and modern classroom. As much as the latest technology and innovation may bring change to the school, it can never replace the teacher.

The arrival of new technology itself means there is a greater need for teachers. Teachers in modern times need to utilize the technology accordingly and use it where appropriate. There is a link between the usage of technology and the role model method that teachers can use in teaching the young generation. Since teachers become the example of students in the school, they can use the video, for example, to teach moral education to the students while letting them see an excellent example in the teacher.

There is some viewpoint from people about incorporating modern technology with the role model method in the class. Some suggested that future teachers will have personalized tech-infused learning as the future education. This type of learning is where the teachers share the best education technology resources around the world. It is more focused on bringing and speeding the technology education through teachers, parents and students.

The teacher can use the technology to give the students assignment related to the lesson they had taught. Rather than doing class activities using the traditional way, they can work on the project on the internet. Here, the teacher can ask the students to be honest while doing their work to not cheat or search for anything else while on the net.

Other than that, the teacher can ask the students to search for anything related to moral values through video or website and analyze it. Teachers can guide the students, facilitate their work, and helps them when necessary without ignoring and focusing on some students. When talking to the students, too, teachers should lower and soften their words so that students can easily catch the word and do not feel burden when doing the work asked.

This finding is in line with Salasiah et al. (2011) where they identified some factors that can enhance learning, including the choice of peers. According to Latefah AlKaderi in her review on Prophet as an educator mentioned that; The Prophet Muhammad said, "The person follows the religion [or habits] of his friends; so each one should consider whom he makes his friend".

This is to prove that peers also contributed to the development of motivation in learning among students. 
119 Al-Hayat: Journal of Islamic Education (AJIE)

e-ISSN: 2599-3046 (online) | Volume 5, Issue 1 | January -June 2021

p-ISSN:2657-1781 (print)

\section{CONCLUSION}

In conclusion, this study showed how much motivation influenced students' memorization of the Quran. The finding suggested that parental guidance and advice were the most influential factors leading to cause among students in memorising the Quran. In addition to this, the students themselves and teachers also were the source of motivation to learn. At the same time, teachers should always assist and help students in their memorization of the Quran. That way, students will feel more confident to continue their memorization. Therefore, this study can be helpful as a reference in lowering the gap on motivation in Quranic memorization. Hence, the researchers believe that this study will help the other researchers continue and elaborate more on Quranic memorization about the cause.

\section{REFERENCES}

[1] Abdullah Yusuf Ali. (1996). The holy quran: text and translation. Kuala Lumpur: Islamic Book Trust.

[2] Abdul Muhsin \& Raghib as-Sirjani. (2015). 'Orang Sibuk pun Bisa Hafal AlQuran' (Busy people would also memorize the Quran) PQS Publishing, Jakarta ISBN : 9786021874899

[3] Adam, M.L. (2016).Factors affecting students' motivation towards learning

[4] Islamic education subject in secondary school. International Islamic University Malaysia: Unpublished Master thesis.

[5] Al-Amin Tahfiz Center. (2012). Maklumat am program. Al-Quran \& Sunnah Department:Sekolah Menengah Islam Al-Amin.

[6] Alizi, A., \& Mohammad Zaki, S. (2005). Psychology of motivation from an

[7] Islamic perspective. Paper presented at 3rd International Seminar on Learning and Motivation. Organized by Faculty of Cognitive Sciences \& Education, Universiti Utara Malaysia, Kedah, Malaysia.

[8] Aragon, S. R. (2002). An investigation of factors influencing classroom

[9] motivation for postsecondary American indian/ Alaska native students. Journal of American Indian Education, 41 (1), 1-18.

[10] Azizi Yahaya. (2006). Self concept and motivation to learn among students. Faculty of Education, Malaysian University of Technology. Retrieved on September 10, 2014 from http://eprints.utm.my.

[11] Brophy, J. (1998). Motivating students to learn. New York: Mc Graw Hill.

[12] Chang, H.H. (2005). The relationship between extrinsic/intrinsic motivation andlanguage learning strategies among college students of English in Taiwan. Master thesis.

[13] Cik Wan Noorli, R., Che Haslina, A. \& Tengku Muhaini, T.M. (May 2011).

[14] Exploring the potential use of video in increasing learnes' understanding and motivation. Institute of Research, Development and Commercialization: Mara University of Technology, Malaysia, 1-18. 
[15] Debnath, S.C. (2005). College student motivation: An Interdisciplinary Approach to an integrated learning system model. Journal of Behavioral and Applied Management, 6(3), 168-189.

[16] D'souza, K.A. \& Maheshwari, S. K. (2010). Factors influencing student performance in theintroductory management science course. Academy of Educational Leadership Journal, 14(3), 99-120.

[17] Entwistle, N. \& Entwistle, D. (2003). Preparing for examinations: the interplay of memorizing and understanding, and the development of knowledge objects. Higher Education Research \& Development.

[18]Free Online Dictionary with sample sentences. (2020). Retrieved from www.dictionary30.com.

[19] Fuhrman, S. H. \& O'day, J.A. (1996). Rewards and reform: creating educational incentives that work. San Francisco: Jossey-Bass, Publishers.

[20] Ghenghesh, P. (May 2010). The motivation of learners of Arabic: Does it decreasewith age? Journal of Language Teaching and Research, 1(3), 235-249.

[21] Hajarul Bahti, Z., Ab Halim, T, Norshidah, M.S. \& Mohd Huzairi, A. (2014). Students attitudes towards learning al-Quran recitation and its relationship with the mastery of reading the al-Quran among visual impaired students in Malaysia. International Conference on Economics, Education and Humanities, Dec 10-11, 97 100.

[22] Huitt, W. (2011). Motivation to learn: An overview. Educational Psychology Interactive.Valdosta, GA: Valdosta State University. Retrieved from http://www.edpsycinteractive.org/topics/motivation/motivate.html

[23] Ikhtisas Circular Letter: Kementerian Pendidikan Malaysia. (2016). Pelaksanaan Tahfiz Model Ulul Albab Di Sekolah Menengah Kementerian Pendidikan Malaysia. (January 15).

[24] Ikhwan, Afiful. Anwar, Saiful. Mahmudah dan Nashikhatun. (2021). Tahsin and Tahfidz Learning System at Integrated Islamic Elementary School (SDIT) Insan Madani During the Pandemic Covid-19. Al-Hayat: Journal of Islamic Education (AJIE), 5(1), 1-11.

[25] Khairul Adzha Shahrudin, Zaidi Mohamad Nusran, \& Siti Jumaah Rahmat.(2015). Penguasaan hukum ra' ketika membaca al-Quran dalam kalangan murid tahun enam. Institut Pendidikan Guru: Kampus Pendidikan Islam. Retrieved on July 14, 2015 from http://www.ipislam.edu.my/index.php/research/read/15/PenguasaanHukum-Ra-Ketika-Membaca-Al-Quran-dalam-Kalangan-Murid-Tahun-Enam.

[26] Muhammad Ikhwanuddin. (2013). The relationships between memorization techniques and understanding of the Quran. Unpublished Master thesis.

[27] Nadia, L. (2012). Critical reading: Devotional reflections in the pursuit of quranicunderstanding in contemporary Pakistan. Unpublished Doctoral Dissertation.

[28] Norkhairolizah Hamzah. (2005). Parental role in promoting children's quranic memorization. Unpublished Master thesis.

[29] Nor Musliza Mustafa. \& Mokmin Basri. (2014). Perbandingan kaedah hafazan al- 
Quran tradisional dan moden: satu kajian awal. Proceeding of the Social Sciences Research ICSSR 2014, 9-10 June: Kota Kinabalu, Sabah.

[30] Ola, A. K., \& Kole, J. (1991). An Islamic perspective on the expectancy-valence theory. The American Journal of Islamic Science, 8(3), 453-460.

[31] Oxford dictionaries of English (2014). Online version. Oxford University Press. Retrieved on May 25, 2015 from www.oxforddictionaries.com

[32] Palmer, D. (2007). What is the best way to motivate students in science? Teacher science. The Journal of the Australian Science Teachers Association, 53(1), 38-42.

[33] Pintrich, G. (1996). Motives, goals and adaptive patterns of performance in asianamerican and anglo-american students. Learning and Individual Differences, 15, 141-158.

[34] Pulido, D., Miraflores, E., Ignacio, A., Tacay, M. \& Lao, J. (2010). A study on the intrinsic motivation factors in second language learning among selected freshman students. Philippine ESL Journal, 4, 3-23.

[35] Rangkaian PITAS. (2016). Persatuan Institut Tahfiz Selangor (PITAS). Retrieved on Jan 26, 2016 fromhttp://tahfizselangor.org/index.php?option=com_content $\&$ view $=$ article $\&$ id $=40$ $5 \&$ Itemid $=573$.

[36] Saudullah Ali. (2003). Students' opinion on teaching strategies to motivate to learn Islamic studies in secondary schools of Maldives. Unpublished Master thesis.

[37] Senarai institut tahfiz di seluruh Malaysia. (2011). Penyelaras Pembangunan A1$\begin{array}{llll}\text { Quran. } & \text { Retrievedon } & \text { July } & 14,\end{array}$ fromhttp://www.darulquran.gov.my/index.php?option=com_content\&view=article \&id=158\%3Asenarai-institut-tahfiz-di-seluruh-malaysia\&catid=45\%3Adewanhuffaz-kebangsaan \&Itemid=1

[38] Sulaiman Ibn al-Asy'ath bin Ishaq al-Azdiyy al-Sijistani (2000). Kitab alsunan:Sunan Abi Daud. Beirut, Dar Ihya’ al-Turath al-'Arabi.

[39] Tongsilp, A. (2013). A path analysis of relationship between factors withachievement motivation of students of private universities in Bangkok, Thailand. Social and Behavioral Sciences Symposium, 4th International Science, Social Science, Engineering and Energy Conference 2012, 229-238.

[40] Tuckman B.W. \& Monetti, D. M. (2010). Educational psychology. USA: Wadsworth Cengage Learning.

[41] Wirth, K.R., \& Perkins, D. (2007). Learning to learn. Retrieved on June 15, 2015 from cgiss.boisestate.edu/ billc/Teaching/Items/learningtolearn

[42]Zaiton, M. \& Hishamuddin, S. (2012). Factors affecting students' interest inlearning Islamic education. Journal of Education and Practice, 3(13), 81-86.

[43]Zukhrufin, Fina Kholij. Anwar, Saiful. Sidiq, Umar (2021). Desain Pembelajaran Akhlak Melalui Mata Pelajaran Pendidikan Agama Islam. JIE: Journal of Islamic Edication, 6(1), 17-35. 